Available online on 15.07.2021 at http://ujpr.org
Universal Journal of Pharmaceutical Research
An International Peer Reviewed Journal
Open access to Pharmaceutical research

\title{
EFFECT OF THE AQUEOUS EXTRACT OF CLERODENDRUM THOMSONIAE LINN (VERBENACEAE) LEA VES ON TYPE 2 DIABETIC WISTAR RATS INDUCED BY THE MACAPOS1 TYPE DIET AND DEXAMETHASONE
}

Eric Martial Deutchoua Ngounou ${ }^{1,4} *$ D, Yannick Dimitry Mang $^{2,4}$, Faustin Dongmo ${ }^{2,4}(\mathbb{D}$, Oumar Waassili Ibrahim Malla ${ }^{3}$ (D), Sélestin Sokeng Dongmo ${ }^{1}$, Nicolas Njintang Yanou ${ }^{1,4}($ DD

${ }^{1}$ Health Medicinal Plant Laboratory and Galenic Formulation, Department of Biological Sciences, Faculty of Science, University of Ngaoundere- $\mathrm{PO}$ BOX 454, Ngaoundere-Cameroon.

${ }^{2}$ Department of Tourism and Hotel management, Higher Technical Teachers' Training College, University of Yaounde I-PO BOX 886, Ebolowa-Cameroon.

${ }^{3}$ Laboratory of Animal Physiology, Department of Biology and Animal Physiology, Faculty of Science, University of Yaounde 1PO BOX 812, Yaounde-Cameroon.

${ }^{4}$ Laboratory of Biophysics and Food Biochemistry and Nutrition, Department of Food Science and Nutrition, ENSAI, University of Ngaoundere- $P O B O X$ 455, Ngaoundere-Cameroon.

\section{ABSTRACT}

Aim and objective: Clerodendrum thomsoniae leaves are used in Cameroon to manage diabetes and its related disorders. The study aimed at investigating the antidiabetic effect of the aqueous extract on diet and dexamethasone induced diabetic rats.

Methods: Young mature leaves of $C$. thomsoniae were dried, finely powdered and submitted to aqueous extraction. The dehydrated extract was tested in rats at 3 doses $312.5,625$ and $1250 \mathrm{mg} / \mathrm{kg}$ based on the local use of the plant. The effect of the extract on the fasting blood glucose in normoglycemic rats and MACAPOS 1 type diet induced diabetic rats, using respectively glibenclamide and metformin as positive control groups, were investigated.

Results: AECT significantly reduced blood glucose levels in normoglycemic rats $(p<0.05)$ two hours after administration, from $83 \pm 2 \mathrm{mg} / \mathrm{dL}$ to $57.39 \pm 1.7 \mathrm{mg} / \mathrm{dL}$ with the dose of $1250 \mathrm{mg} / \mathrm{kg}$ given the highest reduction rate of $30.86 \%$. In normoglycemic rats 30 minutes after oral glucose overload, the maximum reduction rate was observed with glibenclamide $5 \mathrm{mg} / \mathrm{kg}$ and calculated at $49.90 \%$ followed by $36.39 \%$, for the extract at $1250 \mathrm{mg} / \mathrm{kg}$. After 30 days of repeated oral administration, AECT produced a reduction on blood glucose levels $(p<0.05)$ in type 2 diabetic rats. This reduction in blood sugar was much more expressed with the dose of $1250 \mathrm{mg} / \mathrm{kg}(73.52 \pm 0.71 \mathrm{mg} / \mathrm{dL})$ followed by metformin $38 \mathrm{mg} / \mathrm{kg}(70.21 \pm 0.89 \mathrm{mg} / \mathrm{dL})$ as the normal control with no significant difference $(\mathrm{P}<0.05)$.

Conclusion: These results show that the antidiabetic activity of AECT can be explained by insulin stimulating effect, also give support to the traditional use of this plant.

Keywords: Antidiabetic, aqueous extract, Clerodendrum thomsoniae leaves, Dexamethasone, hypoglycemic, MACAPOS 1 diet.

Article Info: Received 11 April 2021; Revised 22 May; Accepted 30 June, Available online 15 July 2021

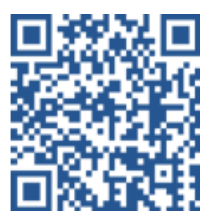

Cite this article-

Ngounou EMD, Mang YD, Dongmo F, Malla OWI, Dongmo SS, Yanou NN. Effect of the aqueous extract of Clerodendrum thomsoniae linn (verbenaceae) leaves on type 2 diabetic wistar rats induced by the MACAPOS1 type diet and dexamethasone. Universal Journal of Pharmaceutical Research 2021; 6(3):9-16.

DOI: https://doi.org/10.22270/ujpr.v6i3.601

Address for Correspondence

Deutchoua Ngounou Eric Martial, Health Medicinal Plant Laboratory and Galenic Formulation, Department of Biological Sciences, Faculty of Science, University of Ngaoundere- PO BOX 454, Ngaoundere, Cameroon. Tel-(237) 670683413;

E-mail: ericmartialdeutch@gmail.com

\section{INTRODUCTION}

African populations use many plants to treat diabetes type 2 and related disorders, thanks to their diversified flora. Diabetes mellitus (DM) is a metabolic disorder due to insufficiency or improper use of insulin characterized by fasting blood sugar above $1.26 \mathrm{gL}^{-1}$ checked twice ${ }^{1}$. While the incidence of the disease is still on progress, with an estimated increase to $72 \%$ by year 2025 and an affected population of 472.6 million by $2045, \mathrm{DM}$ is more and more a global public health problem ${ }^{2}$. According to reported data, DM is mostly frequent in rural area and type 2 accounted for about $80 \%$ of all forms of DM in both sexes ${ }^{3,4}$. Type $2 \mathrm{DM}$ is a chronic and progressive syndrome characterized by metabolic abnormalities such as insulin resistance and 
decreased pancreatic b-cell function that modifies fuelsensing processes in the body ${ }^{5}$. DM is primarily treated with insulin and oral antidiabetic drugs such as biguanides, alpha glucosidase inhibitors, sulphonylureas and glinides ${ }^{6}$. These drugs do not only have negative side effects, but also are expensive, in particular for individuals in developing countries given their low purchasing power. In this respect the traditional pharmacopoeia offers a solution.

Since ancient times, more than $80 \%$ of the world population used plant extracts or any other form to threat many diseases including $\mathrm{DM}^{7,8}$. At least 12000 plants in the world are used for medicinal purposes, but less than $10 \%$ of them are investigated from pharmacological point of view 9 . Many antidiabetic wild plant species have been investigated for their hypoglycemic activity ${ }^{10}$ and actually recommended for therapeutic treatment of $\mathrm{DM}^{11}$. The anti-diabetic effects of plants have been attributed to their contents which include carotenoids, flavonoids, terpenoids, alkaloids, glycosides ${ }^{12}$. Amongst plants studied for their antidiabetic activies we may cite Anacardium occidental $^{13}$, Allium sativum ${ }^{14}$, Allium cepa ${ }^{15}$. Thought Clerodendrum sp. are granted strong therapeutic potentials ${ }^{16}$, Clerodendrum thomsoniae an ornamental plant $^{16}$ widely used by traditional healers in Ngaoundere-Cameroon to treat diabetes, has not yet been investigated. According to the literature, the plant leaves are traditionally used in the treatment of intestinal worms and other illnesses. In addition, the hypolipidemic, the antioxidant activity ${ }^{17}$ and the toxicity $^{18}$ of the aqueous extract of the leaves were studied. The plant activity of the plant was attributed to its high flavonoid and tannin contents ${ }^{17}$.

The general objective of this work was to evaluate the hypoglycemic and antidiabetic activities of aqueous extracts of $C$. thomsoniae on type 2 diabetic rats induced by MACAPOS 1 type diet and dexamethasone.

\section{MATERIALS AND METHODS}

\section{Sampling and production of $\boldsymbol{C}$. thomsoniae extract}

The plant material (leaves) was collected at Mbideng, a neighborhood of Ngaoundéré, in Adamawa region of Cameroon. The plant was identified at the national herbarium $\left(\mathrm{N}^{\mathrm{O}}\right.$ Letouzey 11090 from the herbarium collection NO 28476/SRF/Yaoundé, Cameroon). Young mature leaves of the plant were carefully cleaned, sorted, graded according to size and dried in a ventilated electric turning dryer (brand Riviera \& Bar) at $40 \pm 2{ }^{\circ} \mathrm{C}$ for $48 \mathrm{~h}$. After drying, the leaves were ground to make a fine powder using an electric grinder (Culatti, Polymix, France) equipped with a sieve of diameter $500 \mu \mathrm{m}$ mesh.

\section{Preparation of $\boldsymbol{C}$. thomsoniae aqueous extract}

The obtained powder $(2.5 \mathrm{~g})$ was blended with $40 \mathrm{~mL}$ distilled water. The different mixtures were placed in a water bath at $70 \pm 2{ }^{\circ} \mathrm{C}$ and extracted for 30 min under stirring. The mixture was then cooled for $30 \mathrm{~min}$ and centrifuged at $1500 \mathrm{~g}$ for $15 \mathrm{~min}$ at $20^{\circ} \mathrm{C}$ using refrigerated centrifuge. The supernatant was collected and the residue was solubilized in $40 \mathrm{~mL}$ and re- extracted as mentioned above. The supernatants were combined and concentrated under vacuum in a rotary evaporator and dried in a desiccator at $40^{\circ} \mathrm{C}$. The crude extract was weighed and used to prepare $31.25,62.5$ and $125 \mathrm{mg} / \mathrm{mL}$ aqueous extract of C. thomsoniae (AECT) corresponding to the 3 tested doses (312.5, 625 and $1250 \mathrm{mg} / \mathrm{kg}$ ).

\section{Animal experiments}

To conduct this experiment, healthy Wistar rats all male aged between $6-8$ weeks old and weighing about $150-200 \mathrm{~g}$ were raised in the animal house of the Faculty of Science of the University of Ngaoundéré (Cameroon) at an ambient temperature of $22 \pm 3^{\circ} \mathrm{C}$ and relative humidity of $54 \pm 2 \%$ under a $12 \mathrm{~h} / 12 \mathrm{~h}$ light/dark cycle. The animals were acclimatized to laboratory condition for four days before the experiment starts and were fed with a standard diet made of casein as a protein source and tap water $a d$ libitum. The experiment was carried out as per the guidelines of Committee for the Purpose of Control and Supervision of Experiments on Animals (CPCSEA) and ethically approved by the Institutional Committee of the Ministry of Scientific Research and Innovation of Cameroon (Phone: 00(237)699870979

Effect of single oral administration of AECT in normal healthy rats

This study was done as reported by Kouambou et al., ${ }^{19}$ with some modifications. Twenty rats were divided into four experimental groups with five animals in each group: normal control (NC) rats that received only distilled water $10 \mathrm{~mL} / \mathrm{kg} ; 3$ test groups as used by traditional practitioners (AECT312.5 mg/kg; AECT625 $\mathrm{mg} / \mathrm{kg}$; and AECT1250 $\mathrm{mg} / \mathrm{kg}$ ). For this study, administration of the aqueous extract was done by gavage using a $2.5 \mathrm{~mL}$ goading probe. Blood samples were collected from the tail vein periodically at $\mathrm{t}=0,60$, 90 and $120 \mathrm{~min}$ after the administration of extract and the glucose content determined using glucose oxidase method.

Oral Glucose Tolerance Test (OGTT) in normal Rats

The anti-hyperglycemic effect of the AECT at doses of $312.5,625$ and $1250 \mathrm{mg} / \mathrm{kg}$ was studied as described by Nkono et al., ${ }^{20}$ with some modifications. In this respect, 25 rats were fasted for $16 \mathrm{~h}$ and treated with the AECT (test groups), glibenclamide $5 \mathrm{mg} / \mathrm{kg}$ (positive control group) and water (Normal control group, NC). At time $0 \mathrm{~min}$, the animals were administered orally $10 \mathrm{~mL}$ of the extract, glibenclamide or water. After $30 \mathrm{~min}$ of the treatment, all groups received glucose $(2.5 \mathrm{~g} / \mathrm{kg}$ b.m) orally and the blood glucose concentrations were determined from the tip of a tail at time $0,60,90$ and $150 \mathrm{~min}$..

\section{Induction and Treatment of Hyperglycemia Diabetes induction}

Diabetes was induced in Rats using the MACAPOS 1 diet and dexamethasone according to Kamgang et al., ${ }^{21}$ with some modifications.In the procedure, healthy rats were divided in two groups. One group (normal control) was submitted to standard diet, another group was submitted per os to Sweetened high-calorie diet (SHCD) made of dextrose $0.8 \mathrm{~g} / \mathrm{kg}$ (Gwaudan Laviretteet Cie, Glucose pure Anhydre) and sucrose 4 
$\mathrm{g} / \mathrm{kg}$ (SOSUCAM, Bandjock-Cameroon) every two days. One month after the beginning of SHCD, the animals received the dexamethasone $(25 \mu \mathrm{g} / \mathrm{kg}$ b.m i.m.) once every 2 days during 3 weeks. During the induction period, fasting glycemia was estimated at the beginning and at the end to confirm the onset of diabetes. In this respect the oral glucose tolerance test (OGTT) was carried out by administration of $4 \mathrm{~g} / \mathrm{kg}$ b.m. of D-glucose in rats of different groups. Blood sugar was monitored for $120 \mathrm{~min}$. The animals with fasting total blood glycemia $\geq 126 \mathrm{mg} / \mathrm{dL}$ were considered as diabetic and were selected for the next stage of experiment.

\section{Evaluation of antidiabetic activity of $A E C T$}

The rats were organized into 6 groups of 5 animals each: normal control, negative control group made of diabetic rats receiving water, positive control group made of diabetic rats treated with Metformin (38 $\mathrm{mg} / \mathrm{kg}$ b.m: Met38), test groups composed of diabetic rats treated with aqueous extract of $C$. thomsoniae doses 312.5, 625 and $1250 \mathrm{mg} / \mathrm{kg}$ b.m (AECT312.5, AECT625, AECT1250). The animals were treated once daily by intra-gastric gavages for 30 consecutive days. During the treatment, fasting glycemia was estimated at the beginning and every fifteen days. Other parameters such as food intake, water intake and change in body mass were also measured. At the end of treatment, OGTT and organ to body mass were evaluated as previously described. In addition, animals were sacrificed and dissected and the visceral adipose, hepatic, cardiac and testicular tissues were removed, and weighed.

\section{Statistical analysis}

All data were expressed as mean \pm standard deviation and were statistically analyzed using one-way analysis of variance (ANOVA). When statistical differences were found, the Duncan's Multiple Range Test was applied in order to classify samples at the significance level of 5\%. The Statgraphics Program (Statically Graphics Educational, version 6.0, 1992, Manugistics, Inc. and Statistical Graphics Corp., USA) was used for the statistical analysis.

\section{RESULTS}

Hypoglycemic effect of aqueous extract of $C$. thomsoniae on normoglycaemic rats

The effect of AECT on blood glucose levels in fasting normal rats is presented in Figure 1. A single administration of AECT at all the doses exhibited a significant hypoglycemic effect after 2 hours $(p<0.05)$.

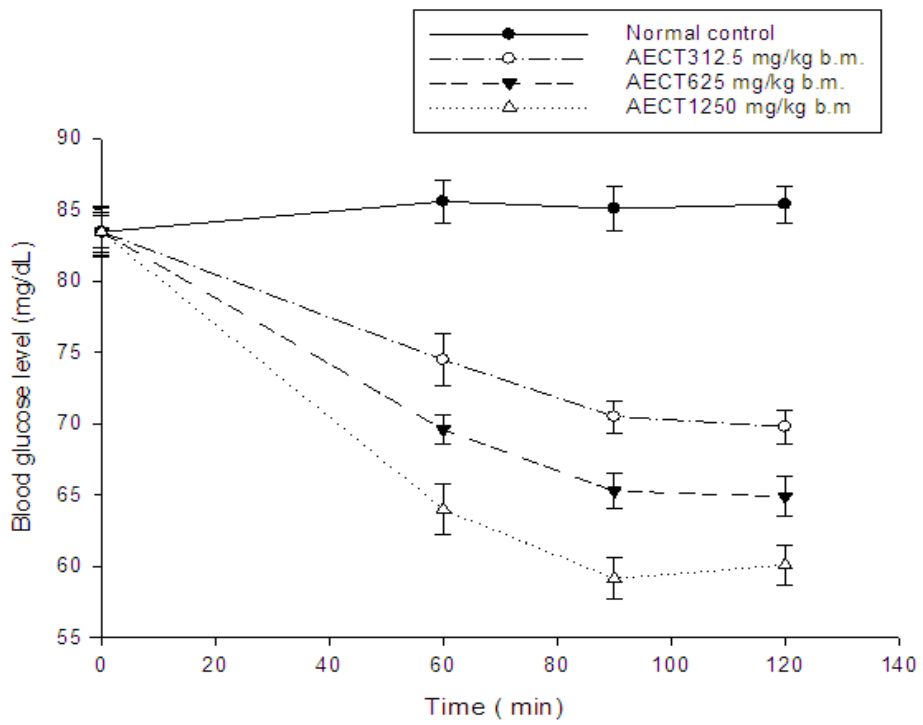

Figure 1: Effect of the aqueous extract of $C$. thomsoniae on blood glucose of normoglycemic rats.

Value are means $\pm \mathrm{SD}(\mathrm{n}=5)$ significantly different $(p<0.05)$ as determined by Duncan's multiple range test. Normal: group of normal rats received distilled water; AECT312.5: group of rats receiving C. thomsoniae extract at dose of $312.5 \mathrm{mg} / \mathrm{kg}$; AECT625: group of rats receiving $C$.

thomsoniae extract at dose of $625 \mathrm{mg} / \mathrm{kg}$; AECT1250: group of rats receiving C. thomsoniae extract at dose of $1250 \mathrm{mg} / \mathrm{kg}$. b.m=body mass

The extract at $1250 \mathrm{mg} / \mathrm{kg}$ produced the most significant reduction $(29.1 \%)(p<0.05)$ comparatively to the effect of the two others doses $(15.5 \%, 21.8 \%$ respectively) 90 min after administration.

Consequently, blood sugar tended to stabilize until the $120^{\text {th }}$ minute when there has been no significant change compared to the $90^{\text {th }}$ minute regardless.
Effects of AECT on Glucose-Induced Hyperglycemia in normal rats
Blood glucose levels returned to baseline or even lower 2 hours after glucose administration in all animals. Animals treated with glibenclamide and AECT showed decreases in blood glucose level 2 hours after glucose administration as shown in Figure 2. In particular, the rats receiving glibenclamide and AECT at $1250 \mathrm{mg} / \mathrm{kg}$ dose showed significant reductions in blood glucose level $30 \mathrm{~min}$ after glucose administration compared with the normal control rats. 


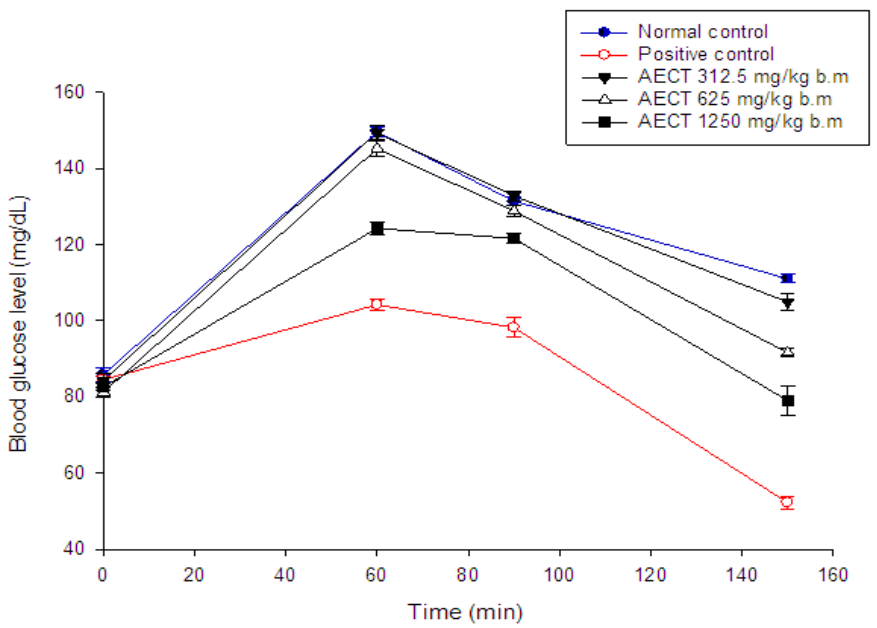

Figure 2: Effect of the aqueous extract of $C$. thomsoniae on oral glucose overload.

Value are means $\pm \mathrm{SD}(\mathrm{n}=5)$ significantly different $(p<0.05)$ as determined by Duncan's multiple range test. Normal control: group of normal rats received distilled water; AECT312.5: group of rats received $C$. thomsoniae extract at dose of $312.5 \mathrm{mg} / \mathrm{kg}$; AECT625: group of rats received $C$. thomsoniae extract at dose of $625 \mathrm{mg} / \mathrm{kg}$; AECT1250: group of rats received C. thomsoniae extract at dose of $1250 \mathrm{mg} / \mathrm{kg}$. Positive control: Group

of rats received glibenclamide. AECT=Aqueous extract of Clerodendrum thomsoniae. b.m = body mass

In the acute test, the glucose load increased blood sugar in the normal control group. The basal glucose in rats in this group increased from $85.8 \pm 2$ to $149.6 \pm 1.43$ $\mathrm{mg} / \mathrm{dL}$ at $30 \mathrm{~min}$ after glucose administration and returned to $111.0 \pm 1.1 \mathrm{mg} / \mathrm{dL}$ after $150 \mathrm{~min}$.

Glibenclamide significantly prevented the rise in blood glucose throughout the experiment followed by AECT at dose of $1250 \mathrm{mg} / \mathrm{kg}$.

Oral glucose tolerance test at the end of induction of type 2 diabetes
Figure 3 shows the glycemic response of rats submitted to sweetened high-calorie and dexamethasone regime and compared to normal rats. OGTT in normal rats resulted in an increase in blood sugar at $60 \mathrm{~min}(122.50$ $\mathrm{mg} / \mathrm{dL}$ ), then a decrease within $120 \mathrm{~min}$ to an identical value $(72.33 \pm 2.80 \mathrm{md} / \mathrm{dL})$ at baseline blood sugar. In diabetic rats, the glycemia significantly linearly increased $(P<0.05)$ from $130 \pm 2$ to $148 \pm 2 \mathrm{mg} / \mathrm{dL}$, passing by a value of $137.33 \mathrm{mg} / \mathrm{dL}$ at $60 \mathrm{~min}$.

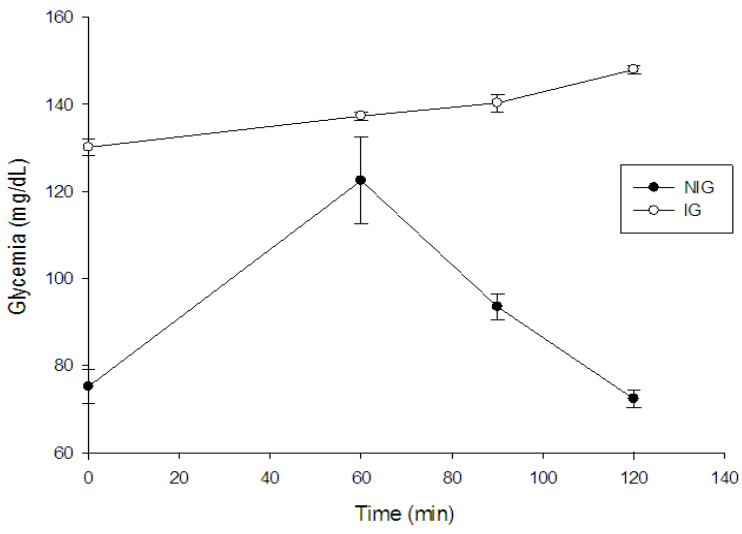

Figure 3: Change in blood sugar after an oral overload of a glucose solution at the end of induction period (4g/kg b.m).

NIG: Non-Induced Group; IG: Induced Group; min: minute; The means are significantly different $(\mathrm{P}<0.05)$; Values were expressed as mean \pm standard deviation; $\mathrm{n}=5$.

\section{Diabetes treatment}

Effect of $C$. thomsoniae extract on fasting glucose in type 2 diabetic rats

Table 1 presents the effect of AECT on blood glucose level during each period of 15 days on normal and type 2 induced diabetic rats for 30 days experimental period.Administration of Sweetened high-calorie diet (MACAPOS 1) led to an increase in the blood glucose levels in induced rats compared to those of normal control. However, 30 days treatment with AECT at the three doses resulted to a marked decrease in blood glucose. For diabetics' rats receiving placebo, glycemia remained very high compared to the normal control
$(128 \pm 2,6$ vs $74.2 \pm 1.92 \mathrm{mg} / \mathrm{dL})$. The glycemia of test groups treated AECT decreased whatever the dose ($22.14 \pm 1.67 \%$; $-24.73 \pm 1.1 \%$; $-43.90 \pm 1.73 \%$ and $44.9 \pm 1.35 \%$ ) respectively for AECT312.5, AECT625, AECT1250) and metformin. The reductions were significant $(P<0.05)$ compared to the negative control. The observed decrease was more pronounced with the treatment AECT at dose $1250 \mathrm{mg} / \mathrm{kg}$, leading to a glycemia comparable to that of normal control group the $30^{\text {th }}$ day $(73.5 \pm 0.7$ and $74.2 \pm 1.9 \mathrm{mg} / \mathrm{dL}$ respectively). No significant $(P<0.05)$ difference was observed between normal control, positive control and 
test group AECT dose $1250 \mathrm{mg} / \mathrm{kg}$ at the end of treatment.

The Effects of aqueous extract of $C$. thomsoniae on gain in body mass, water intake, food intake and glycemia parameters in induced type 2 diabetic rats The Effects of aqueous extract of $C$. thomsoniae on change in body mass, water intake, food intake parameters on induced type 2 diabetic rats are summarized in Table 1. During 30 days of the treatment of diabetic rats, the body mass of rats in positive control group (PC) and test groups irrespective of the dose gradually decreased at the end of the treatment, these groups also showed significant reductions $(p<0.05)$. The drop in body mass was higher with the extract at the dose $1250 \mathrm{mg} / \mathrm{kg}$ and metformin (respectively $-16.07 \pm 10.00 \mathrm{~g}$ and $-18.39 \pm 4.74 \mathrm{~g}$ ). It has also been observed a significant reduction in food intake and water intake in groups administered AECT as compared to the diabetic group (NC) $(p<0.05)$.

Assessment of abdominal fat at the end of treatment The effects of AECT administration on the abdominal fat of diabetic rats are presented in Figure 4. It appears from this figure that the relative mass of abdominal fat decreased during treatment. Administration of AECT reduced abdominal fat with the magnitude increasing with the dose with $1250 \mathrm{mg} / \mathrm{kg}$ inducing reduction $64.52 \%$ while reduction in Metformime group was $59 \%$.

\section{DISCUSSION}

Plants have always been the major source of drugs, thanks to their content in secondary metabolites ${ }^{22,23}$. In this vein, thousands of plants are traditionally used for the treatment of diabetes mellitus and its complications, however to the best of the knowledge, no study has been conducted on the hypoglycemic and antidiabetic properties of AECT in vivo. The effect of the AECT on normoglycemic animals suggested that the leaves of $C$. thomsoniae has a mild lowering effect on normal glucose levels. This effect was comparable to that of glibenclamide, an insulin secretagogue, which also lowers blood glucose in normal animals. Provided the $\beta$-cells are fully functional, sulphonylureas, such as glibenclamide, can cause hypoglycemia since insulin release is initiated even when glucose concentrations are below the normal threshold for glucose stimulated insulin release (approximately $5 \mathrm{mmol} / \mathrm{L}$ or $90 \mathrm{mg} / \mathrm{dl})^{24}$. The results of this study showed a dose-dependent hypoglycemic activity of the aqueous extract of $C$. thomsoniae in normoglycemic rats. These results also suggested that the hypoglycemic effect may be due to water-soluble compounds. It has been established by many studies that the genus Clerodendrum is rich in total phenolic compounds, flavonoids, terpenoids, alkaloids, tannins, saponosides and anthraquinones ${ }^{25,26}$. Our previous studies also revealed that AECT contains these secondary metabolites ${ }^{17}$. As reported by Mamadou ${ }^{27}$, the lowering blood glucose property of Clerodendrum capitatum is dose dependent and based to its level in secondary metabolites. OGTT measures the ability of the body to stabilize the blood glucose to its normal level. The glycemic status of rats was shown to improve as the AECT dose increased in a dosedependent manner. OGTT study revealed diabetic rats treated AECT and glibenclamide exhibited significant ( $p<0.05)$ improvements in their blood glucose levels, with the effect being more effective as the dose of AECT increased. The antihyperglycemic activity of the aqueous extract suggested that $C$. thomsoniae extract contains compounds with a mechanism of action that may be similar to that of glibenclamide. Therefore, AECT may be considered insulin-secreting agent which stimulates the beta cells of the Langerhan islets of the pancreas for insulin production. According to Arumugam et al. ${ }^{28}$, plants may act as antihyperglycemic agent through two mechanisms: increasing insulin secretions or reducing intestinal absorption of glucose. These activities may be associated to their content in some bioactive components revealed earlier in the plant extract ${ }^{17}$. The role of polyphenols in the complexation, and therefore inhibition of $\alpha$-glucosidase and $\alpha$-amylase has been pointed as a mechanism involved in hypoglycemic effect of some plants ${ }^{29}$.

In the current work, a relative stability was found in blood glucose in the diabetic control group which may be due to the insulin resistance very often encountered in obese or type 2 diabetes ${ }^{30}$. However, oral administration of AECT exhibited significant increase in blood glucose levels. Current results indicated that AECT dose $1250 \mathrm{mg} / \mathrm{kg}$ significantly $(p<0.05)$ reduced the level of blood glucose within the third and fourth week of the experimental period. This result strongly supports the antidiabetic property of AECT. However, increasing insulin secretion and maintaining its level within the normal physiological range are very important for antidiabetic therapy. In this experiment, hyperglycemia induced in 10 weeks by the combined effect of MACAPOS 1 type diet and dexamethasone was associated with increase food intake and water intake body mass. Current results are in accordance with many other ${ }^{31}$. Glucocorticoids are known to have particularly significant metabolic side effects on carbohydrate metabolism ${ }^{32}$.

Dexamethasone (exogenous glucocorticoid) provokes the insulin resistance thereby induces chronic hyperglycemia and other metabolic disorders such as increase neo-glucogenesis from amino acid and glycerol in the liver, and lipolysis in adipocytes ${ }^{33}$. Dexamethasone also acts by inhibiting the gene expression of adiponectin, a hormone produced by adipocytes which promotes insulin resistance through dysfunction of hormon receptor in the liver, muscle and adipose tissue ${ }^{34,35}$. Fortunately, AECT significantly ( $\mathrm{p}$ $<0.05$ ) decreased blood sugar levels of diabetic rats to normal value with a maximum decrease observed with the highest dose of AECT $1250 \mathrm{mg} / \mathrm{kg}$ dose. This result suggested that AECT may act among others like metformin, by decreasing hepatic glucose production and ameliorating the peripheral insulin sensitivity ${ }^{36}$. This further indicates the role phytochemicals present in AECT which need investigations in order to identify the molecules responsible for the activity observed. 
Table 1: Parameters measured during treatment.

\begin{tabular}{|c|c|c|c|c|c|c|c|c|c|c|c|c|}
\hline \multirow[t]{2}{*}{ Parameters } & \multicolumn{3}{|c|}{ Water intake } & \multicolumn{3}{|c|}{ Food intake } & \multicolumn{3}{|c|}{ Changes in body mass } & \multicolumn{3}{|c|}{ Glycemia } \\
\hline & Do & D15 & D30 & D0 & D15 & D30 & Do & D15 & D30 & D0 & D15 & D30 \\
\hline Normal & $136 \pm 0.71^{\mathrm{a}}$ & $129.28 \pm 0.84^{b}$ & $129.71 \pm 1.92^{\mathrm{b}}$ & $91.74 \pm 0.71^{\mathrm{a}}$ & $78.51 \pm 0.84^{\mathrm{b}}$ & $77.93 \pm 1.92^{\mathrm{b}}$ & $212.2 \pm 10.9^{\mathrm{a}}$ & $222.5 \pm 8.8^{\mathrm{e}}$ & $226.6 \pm 1.4^{\mathrm{ac}}$ & $75.00 \pm 0.71^{\mathrm{a}}$ & $74.8 \pm 0.84^{\mathrm{a}}$ & $74.2 \pm 1.92^{\mathrm{a}}$ \\
\hline $\mathrm{NC}$ & $264 \pm 1.22^{\mathrm{a}}$ & $255.8 \pm 3.97^{\mathrm{b}}$ & $255 \pm 2.61^{\mathrm{b}}$ & $135.96 \pm 1.22^{\mathrm{a}}$ & $124 \pm 3.97^{\mathrm{b}}$ & $123.00 \pm 2.61^{\mathrm{b}}$ & $261.8 \pm 11.1^{\mathrm{ab}}$ & $255.9 \pm 4.4^{\mathrm{d}}$ & $249.3 \pm 3.6^{\mathrm{b}}$ & $131 \pm 1.22^{\mathrm{b}}$ & $131.00 \pm 3.97$ & $128 \pm 2.61^{\mathrm{b}}$ \\
\hline $\mathrm{PC}$ & $262 \pm 1.67^{\mathrm{a}}$ & $136.28 \pm 1.14^{\mathrm{ab}}$ & $131.85 \pm 0.89^{\mathrm{ac}}$ & $135.88 \pm 1.67^{\mathrm{a}}$ & $76.93 \pm 1.14^{\mathrm{b}}$ & $75.32 \pm 0.89^{\mathrm{b}}$ & $257.2 \pm 15.1^{\mathrm{ab}}$ & $233.7 \pm 8.3^{\mathrm{b}}$ & $219.3 \pm 6.7^{\mathrm{a}}$ & $131 \pm 1.67^{\mathrm{b}}$ & $\underset{\mathrm{ab}}{121.00 \pm 1.14}$ & $70.2 \pm 0.89^{\mathrm{a}}$ \\
\hline AECT312.5 & $269 \pm 1.14^{\mathrm{a}}$ & $135.71 \pm 0.84^{b}$ & $130.57 \pm 0.55^{\mathrm{c}}$ & $136.87 \pm 1.14^{\mathrm{a}}$ & $73.36 \pm 0.84^{\mathrm{b}}$ & $74.29 \pm 0.55^{\mathrm{b}}$ & $262.9 \pm 10.4^{\mathrm{ab}}$ & $240.1 \pm 5.8^{\mathrm{ac}}$ & $236.4 \pm 3.9^{\mathrm{bc}}$ & $131.00 \pm 1.14^{\mathrm{b}}$ & $126.4 \pm 0.84^{\mathrm{c}}$ & $102.4 \pm 0.55^{\mathrm{bc}}$ \\
\hline AECT625 & $260 \pm 1.30^{\mathrm{a}}$ & $137.57 \pm 1.00^{\mathrm{b}}$ & $132.28 \pm 1.14^{\mathrm{c}}$ & $135.83 \pm 1.30^{\mathrm{a}}$ & $74.85 \pm 1.00^{\mathrm{b}}$ & $75.26 \pm 1.14^{\mathrm{b}}$ & $260.1 \pm 13.6^{\mathrm{ab}}$ & $244.8 \pm 7.5^{\mathrm{bc}}$ & $231.7 \pm 2.4^{\mathrm{c}}$ & $131.00 \pm 1.3^{\mathrm{b}}$ & $125.4 \pm 1^{\mathrm{ab}}$ & $98.6 \pm 1.11^{\mathrm{d}}$ \\
\hline AECT1250 & $260 \pm 1.14^{\mathrm{a}}$ & $135.71 \pm 0.84^{\mathrm{ab}}$ & $130.85 \pm 0.71^{\mathrm{b}}$ & $135.9 \pm 1.14^{\mathrm{a}}$ & $76.09 \pm 0.84^{\mathrm{b}}$ & $74.59 \pm 0.71^{\mathrm{c}}$ & $260.2 \pm 12.8^{\mathrm{ab}}$ & $239.9 \pm 8.6^{\mathrm{ac}}$ & $221.8 \pm 5.1^{\mathrm{ac}}$ & $131.00 \pm 1.14^{\mathrm{b}}$ & $123.8 \pm 0.84^{\mathrm{ab}}$ & $73.5 \pm 0.71^{\mathrm{a}}$ \\
\hline
\end{tabular}

The values entered in the table are means \pm standard deviation, with a sample number of " $\mathrm{n}=5$. The means with different letters are significantly different $(\mathrm{P}<0.05)$. AECT: aqueous extract of Clerodendrum thomsoniae $(1250 \mathrm{mg} / \mathrm{kg} \mathrm{m} . c ; 625 \mathrm{mg} / \mathrm{kg} \mathrm{m} . \mathrm{c} ; 312 \mathrm{mg} / \mathrm{kg}$ b.m) N.C: Negative Control (subjected to a Normal Diet + Distilled Water during treatment); P.C: Positive control subjected to a Normal Diet + metformin.

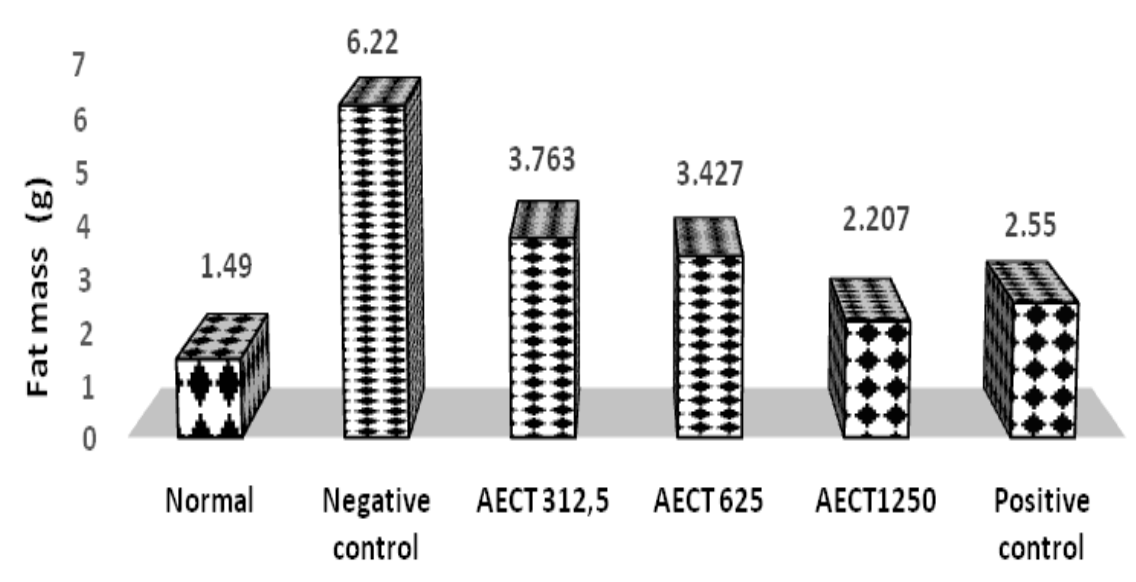

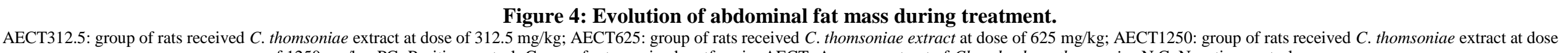
of $1250 \mathrm{mg} / \mathrm{kg}$. PC=Positive control: Group of rats received metformin. AECT=Aqueous extract of Clerodendrum thomsoniae N.C: Negative control 
In anticipation, flavonoids have been shown to improve the sensitivity to insulin and thereby reduced the incidence of type 2 diabetes ${ }^{37,38}$. Concerning abdominal fat, AECT reduce the quantity in a dose-dependent manner with the highest reduction observed at 1250 $\mathrm{mg} / \mathrm{kg}$ of AECT compared to the group of rats treated with metformin. In normal physiological state, insulin activates the lipolytic actions of the hormones on the deposit peripheral fat, hydrolyzing triglycerides and preventing storage of free fatty acids ${ }^{39,40}$. In this experimental study, type 2 diabetic rats- showed significantly elevated quantity of abdominal fat. As expected, treatment with AECT significantly decreased the quantity of fat in the diabetic rats. Sharma et al., ${ }^{29}$ observed a similar hypolipidemic potential of Garcinia pedunculata extract polyphenols in fatty diet rats. Moreover, our previous studies ${ }^{17}$ established the lipidlowering nature of AECT in dyslipidemic rats, thanks to their content in bioactive compounds. In summary, the aqueous extract of $C$. thomsoniae appears to have insulin-stimulating property, which could be useful in the reduction of fat-related problems. According to Cryer $^{41}$ the decrease in fluid intake observed in rats treated with the extract and those with metformin could be linked to the restoration of blood glucose homeostasis. Indeed, the reduction-in blood glucose probably resulted from a decrease in blood osmolarity which is accompanied by a reduction in need for water and consequently, a decrease in fluid intake.

\section{CONCLUSION}

On the basis of the current investigation, it could be concluded that aqueous extract of the leaves of $C$. thomsoniae possess hypoglycaemic and antidiabetic properties, in both normal and diabetic rats. The increase in activity is dose-dependent up to a maximum dose of $1250 \mathrm{mg} / \mathrm{kg}$. To establish the antidiabetic principle(s) however, the putative compound(s) have to be isolated and evaluated. It is therefore, suggested that further purification steps would be necessary to isolate and further evaluate the antidiabetic principles of the plant on animal models.

\section{ACKNOWLEDGEMENTS}

We sincerely thank the Laboratory of Medicinal plants, Health and Pharmaceutical Formulation, Department of Biology of the Faculty of Sciences, Ngaoundere University; and the Laboratory of Food Biophysics and Biochemistry and Nutrition, National School of AgroIndustrial Sciences, University of Ngaoundere for providing all necessary materials, equipment's and facilities to carry out the research.

\section{AUTHORS'S CONTRIBUTION}

EM Deutchoua and YD Mang Conceptualize, EM Deutchoua, F Dongmo and OWM Ibrahim take care of the laboratory work, EM Deutchoua, YD Mang and F Dongmo were involved in designing the experiment, interpreted the data. preparation of the original draft EM Deutchoua and YD Mang, EM Deutchoua and YD
Mang; writing-review and editing, S Dongmo Sokeng.; visualization, $\mathrm{N}$ Yanou Njintang for the supervision.

\section{CONFLICT OF INTEREST}

The authors have declared that there is no conflict of interest.

\section{REFERENCES}

1. Petersmann A, Müller-Wieland D, Müller UA, et al. Definition, classification and diagnosis of diabetes mellitus. Exp Clin Endocrinol Diabetes 2019; 127 (Suppl 1): S1-S7. https://doi.org/10.1055/a-1018-9078

2. Lefèbvre, P. Diabetes yesterday, today and tomorrow. The action of the International Diabetes Federation. Medical J Liège 2005;60 : 273-277.

3. International diabetes federation (FID). Atlas du diabète de la FID $-8^{\text {th }}$ Edition. 2017; 150p

4. Punthakee Z, Goldenberg R, FACE, Pamela Katz MD, FRCPC, 2018. Definition, classification and diagnosis of diabetes, prediabetes and metabolic syndrome. Can J Diabetes 42: S10-S15 https://doi.org/10.1016/j.jcjd.2017.10.003

5. Velingkar VS, Dandekar VD, Murugananthan K. Synthesis and pharmacological evaluation of some novel potent type 2 antidiabetic agents. Int J Pharm Pharm Sci 2009 ;1(1): 149-158. https://doi.org/10.3390/molecules 21020145

6. Thrasher J. Pharmacologic management of type 2 diabetes mellitus:available therapies. Am J Cardiol 2017;120: S4S16.https://doi.org/10.1016/j.amjcard.2017.05.009

7. Yadav JP, Arya V, Yadav S. Cassia occidentalis L.: a review on its ethnobotany, phytochemical and pharmacological profile. Fitoterapia 2010; 81:223-30. https://doi.org/10.1016/j.fitote.2009.09.008

8. Alqathama A, Alluhiabi G, Baghdadi H, et al. Herbal medicine from the perspective of type II diabetic patients and physicians: what is the relationship? BMC Comp Med Therap 2020; 20; 65: 1-9. https://doi.org/10.1186/s12906-020-2854-4

9. Muriira KG. Report Antidiabetic activities of ethyl acetate and aqueous extracts of Pappea capensis, Senna spectabilis, Maytenus obscura, Ocimum americanum and Launaea cornuta [Doctoral dissertation]. Kenyatta University 2014; 202 p.

10. Khan MY, Aziz I, Bihari B, Hemant Kumar H, et al. 2014. A review- phytomedicines used in treatment of diabetes. Int J Pharmacog 2014; 1(6):343-365. https://doi.org/10.13040/IJPSR.0975-8232.1(6).343-65

11. Kooti W, Moradi M, Akbari SA, Sharafi-Ahvazi N, Asadi Samani M, Ashtary-Larky D. Therapeutic and pharmacological potential of Foeniculum vulgare Mill: A review. J Herb Med Pharmacol 2015; 4: 1-9. https://doi.org/10.1016/j.arabjc.2012.04.011

12. Afrisham R, Aberomand M, Ghaffari MA, Siahpoosh A, Jamalan M. Inhibitory effect of Heracleum persicum and Ziziphus jujuba on activity of alpha-amylase. J Bot 2015: 18. https://doi.org/10.1155/2015/824683

13. Sokeng D, Kamtchouing P, Watcho P, et al. Hypoglycemic activity of Anarcardium occidentale L. Aqueous extracts in normal \& Streptozotocin-induced diabetic rats. J Diabet Res 2001; 36: 01-09. https://doi.org/10.18311/ti/2021/v28i2/26775

14. Mahesar H, Bhutto MA, Khand AA, Narejo NT. Garlic used as an alternative medicine to control diabetic mellitus in alloxan-induced male rabbits. Pak J Physiol 2010; 6(1), 39-41.

15. Kim H, Jo H, Kwon I, Hwang K. Effects of onion (Allium сера L.) extract administration on intestinal $\alpha$-glucosidases activities and spikes in postprandial blood glucose levels in SD rats' model. Int J Mol Sci 2011; 12: 3757 - 3769. https://doi.org/10.3390/ijms12063757 
16. Shrivastava N, Patel T. Clerodendrum and healthcare: an overview. Med Aromat Plant Sci Biotechnol 2007; 1:209223.

17. Deutchoua EM, Mang YD, Sokeng DS, Njintang YN. Hypolipidemic and antioxidant activity of aqueous extract of Clerodendrum thomsoniae Linn. (Verbenaceae) leaves in albino rats, Rattus norvegicus (Muridae). J Pharmacog Phytochem 2020; 9(1): 595-602

18. Ngounou EMD, Dongmo F, Mang YD, Dongmo SS, Yanou NN. Evaluation of the acute and subchronic toxicity of the aqueous extract of the leaves of Clerodendrum thomsoniae Linn in oral route. Asian J Pharm Pharmacol 2020; 6(6): 375-382. https://doi.org/10.31024/ajpp.2020.6.6.2

19. Kouambou CCN, Dimo T, Dzeufiet PDD, et al. Antidiabetic and hypolipidemic effects of Canarium schweinfurthii hexane bark extract in streptozotocindiabetic rats. Pharmacol Online 2007;1: 209-219

20. Nkono BLNY, Sokeng SD, Désiré DDP, Kamtchouing P. Antihyperglycemic and antioxydant properties of Alstonia boonei De Wild. (Apocynaceae) stem bark aqueous extract in dexamethasone-induced hyperglycemic rats. Int $\mathbf{J}$ Diabetes Res 2014; 3: 27-35. https://doi.org/10.5923/j.diabetes.20140303.01

21. Kamgang R, Mboumi R, N'dillé G, Yonkeu J. Cameroon local diet-induced glucose intolerance and dyslipidemia in adult Wistar rat. Diabetes Res Clin 2005; 69. 224-30. https://doi.org/10.1016/j.diabres.2005.02.005

22. Hoang-Nam Pham, 2017. Impact of secondary plant metabolites on rhizosphere pathogenic bacteria: is there a link between metal resistance and antibiotic resistance modulation? Agricultural Sciences. Paul Sabatier University - Toulouse III. French. NNT: 2017TOU30153.

23. LOUGBEGNON TO, GBESSO F, LOGBO J, et al. Ethnobotanical study of plants with therapeutic value in the commune of Glazoué in Benin (West Africa). Int J Innov App Stud; Rabat 2018; 24, N²: 644-655. https://doi.org/10.1186/s12906-020-03080-6

24. Krentz AJ, Bailey CJ. Oral antidiabetic agents: current role in type 2 diabetes mellitus. Drugs; 2005; 65 (3): 385-411. https://doi.org/10.2165/00003495-200565030-00005

25. Adeneye AA, Adeleke TI, Adeneye AK Hypoglycemic and hypolipidemic effects of the aqueous fresh leaves extract of Clerodendrum capitatum in wistar rats. J Ethnopharmacol 2008; 116:7-10.https://doi.org/10.1016/j.jep.2007.10.029

26. Linn. Pharm Res 2009; 1:294-298.

27. Mamadou Balde, 2018. Physico-chemical study and valorisation of bioactive compounds of Parinari macrophylla Sabine (Chrysobalanaceae). Theoretical and/or physical chemistry. University of Strasbourg; Cheikh Anta Diop University (Dakar). French. NNT: 2018STRAF013.

28. Arumugam G, Manjula P, Paari N. A review: Anti diabetic medicinal plants used for diabetes mellitus. J Acute Dis 2013; 2:196-200. https://doi.org/10.1016/S2221-6189(13)60126-2

29. Sharma R, Kumari S, Elancheran R, Deori M, Devi R. Polyphenol rich extract of Garcinia pedunculata fruit attenuates the hyperlipidemia induced by high fat diet. Front Pharmacol $2016 ; 7$. https://doi.org/10.3389/fphar.2016.00294

30. Lin HY, Shao-Wen W, Shen FC, 2020. Abrogation of Tolllike receptor 4 (TLR4) mitigates obesity-induced oxidative stress, proinflammation, and insulin resistance through metabolic reprogramming of mitochondria in adipose tissue. Antioxid Redox Signal 2020; 33(2):1-60. https://doi.org/10.1089/ars.2019.7737

31. Mvongo C, Mfopa A, Kamgang R, Essame Oyono JL. Antidiabetic and Antioxidant Activities of Crinum jagus Extracts on Induced Diabetes Rats MACAPOS 1. Int J Pharm Phytochem Ethnomed 2016; 5: 86-95

32. Beaupere C, Liboz A, Fève B, Blondeau B, Guillemain G. Molecular mechanisms of glucocorticoid-induced insulin resistance. Int J Mol Sci 2021; 22, 623. https://doi.org/10.3390/ ijms22020623

33. Sidibeh CO. Novel mechanisms of glucocorticoid-induced insulin resistance in human adipose tissue. Digital comprehensive summaries of uppsala dissertations from the Faculty of Medicine 1408. 52 Uppsala: Acta Universitatis Upsaliensis 2018; ISBN 978-91-513-0180-8.

34. Della Bella E, Buetti-Dinh A, Licandro G, et al. Dexamethasone induces changes in osteogenic differentiation of human mesenchymal stromal cells via SOX9 and PPARG, but Not RUNX2. Int J Mol Sci 2021; 22: 4785. https://doi.org/10.3390/ijms2209478

35. Wego MT, Poualeu SL, Miaffo D, Nchouwet ML, Kamanyi A, Wansi SL. Protective effects of aqueous extract of Baillonella toxisperma stem bark on dexamethasoneinduced insulin resistance in rats. Adv Pharm Sce 2019; 6. https://doi.org/10.1155/2019/8075163

36. Itamar Raz. Guideline approach to therapy in patients with newly diagnosed type 2 diabetes. Diabetes Care 2013; 36 139-144. https://doi.org/10.2337/dcS13-2035

37. Russo B, Picconi F, Malandrucco I, Frontoni S. Flavonoids and insulin-resistance: from molecular evidences to clinical trials. Int J Mol Sci 2019; 20(9): 2061 https://doi.org/10.3390/ijms20092061

38. Guasch-Ferré M, Merino J, Sun Q, Fitó M, Salas-Salvadó J. Dietary polyphenols, mediterranean diet, prediabetes, and type 2 diabetes: a narrative review of the evidence. Oxid Med Cell Longev 2017.https://doi.org/10.1155/2017/6723931

39. Zeka K, Ruparelia K, Arroo R, Budriesi R, Micucci M. Flavonoids and their metabolites: prevention in cardiovascular diseases and diabetes. Diseases 2017; 5:19. https://doi.org/10.3390/diseases5030019

40. Jia Zhao, YaYun Wu, XiangLu Rong, CuiWen Zheng, Jiao Guo. Anti-Lipolysis Induced by Insulin in Diverse Pathophysiologic Conditions of Adipose Tissue. Diabetes, Metabolic Syndrome and Obesity: Targets and Therapy 2020; 13:1575-1585.

https://doi.org/10.2147/DMSO.S250699

41. Mahdi H S, Robert H H, Azuwerus V B, Maaike Goris, Leo ED, Hendrik B., 2017. Metformin improves endothelial function and reduces blood pressure in diabetic spontaneously hypertensive rats independent from glycemia control: comparison to vildagliptin. Sci Reports 2017; 7:10975.https://doi.org/10.1038/541598-01-1130 